\title{
The Impact of Pandemic Covid-19 on Bank Financial Performance (Study at Province Development Bank in Sumatera)
}

\author{
Susfa Yetti Afrizal \\ Lecturer of Faculty Economy and Business of Jambi University-Jambi- Indonesia
}

\begin{abstract}
This research aims to analyze the impact of pandemic covid-19 on bank financial performance and the differences between bank performance before and after pandemic covid-19 at Province Development Bank in Sumatera based on financial criteria: namely the ratio of NPL ( Net Performance Loan Ratio), ROA ( Return on Asset ), ROE ( Return On Equity ), LDR ( Loan Deposit Ratio ) and CAR ( Capital Adequacy Ratio ). This research uses quantitative method by using a comparative approach. Population and samples of this research are all the Province Development Bank in Sumatera ( 8 Banks). Descriptive statistic, Paired Sample Test, and Wilcoxon test were used to analyze these data. The result of this research show that; (1) there were significant differences financial performance on Province Development Bank in Sumatera before and after the pandemic Covid-19 based on NPL and CAR performance criteria. (2) there were no difference in bank financial performance before and after the pandemic Covid-19 based on ROA, ROE and LDR performance criteria.
\end{abstract}

Keywords: Financial Performance, Net Performance Loan, Return On Assets, Return On Equity, Loan to Deposit Ratio, and Capital Adequacy Ratio.

DOI: $10.7176 / \mathrm{RJFA} / 12-22-12$

Publication date: November 30th 2021

\section{INTRODUCTION}

\subsection{Research Background}

Covid 19 has been on going since the announcement in Indonesia around the month of March 2020. Emergenceof pandemic viruses corona or Covid 19 is able paralyze activity all the people who carried out outside the home. The spread of the corona virus is felt to be very fast and uncontrolled, so that the number affected by this virus is increasing both in other countries and in Indonesia itself. Covid 19 is able to weaken the economy globally with a very deratis and very strong repercussions for the business world, Covid 19 have an impact that is very significant to the sectors of finance, including the activities of banks. due to a decrease in the company's revenues and profits

Performance of the company, both are engaged in the field of industry, property, tourism, finance and banking suffered a decline, but there are among the Bank's private and state-owned enterprises and enterprises still shows stable performance, the Regional Development Bank which is owned Bank government area.

During the pandemic, the Indonesian government adopted a policy to focus on three sectors, namely health, the real sector and banking. The Covid-19 pandemic is a problem for banks, because it can produce problems in the real sector or the business world that have the potential to cause problems in the banking sector . Of course, this can happen, because the banking sector is an intermediary or intermediary institution that supports the need for investment funds for the business world .

Regional Development Banking in Indonesia faces a number of challenges amid the Covid-19 outbreak. According to the Regional Development Economic Observer who is also the founder of Karim Consulting, Adiwarman Karim said that the condition of the Regional Development Banking industry could deteriorate earlier than the conventional banking industry .

Crisis economy that occurred in several years that then cause an impact in all aspects of community life, as well as the economic crisis in 2020 that occurred were caused by covid-19 also gives an impact on the sector finance especially sector banks. Regional Development Banks are also not spared in this crisis and no financial sector can escape this crisis. Of course, this economic crisis could affect the Regional Development Bank. Some bank indicators that can be disrupted include: Return on Assets (ROA), Return on Equity (ROE), Non Performing Loans (NPL), Loan to Deposit Ratio (LDR), and Capital Adequacy Ratio (CAR).

In past pandemics Covid-19 today, banks will face some possibility of risk, such as the risk of a credit stand still (NPL) the risk of the market and the risk of liquidity. Therefore, the risk that in the end will have impact on the financial performance of banks. For this reason, it is necessary to conduct research to analyze the impact of Covid-19 on the financial performance of regional development banks. The financial performance that can be seen from the development of NPL as of the first quarter of March 2020 (before covid 19) and NPL as of the second quarter of June 2020 (after covid 19 ) is as follows. 
NPL Financial Performance .

\begin{tabular}{|l|l|l|l|}
\hline Company Name & NPL per quarter I March 2020 & NPL as of the second quarter of June 2020 & $\begin{array}{c}\text { Enhancement } \\
\text { /Descent }\end{array}$ \\
\hline Aceh Bank, & $0.08 \%$ & $0.10 \%$ & Ride \\
\hline Bank of North Sumatra & $3.03 \%$ & 2.87 & down \\
\hline Riau Bank & $0.93 \%$ & $0.95 \%$ & Ride \\
\hline Nagari Bank & $2.02 \%$ & $2.25 \%$ & Ride \\
\hline bank 9 jambi & $0.30 \%$ & $0.41 \%$ & Ride \\
\hline Bank Sumsel & $1.42 \%$ & $1.41 \%$ & down \\
\hline Bengkulu Bank & $0.31 \%$ & $0.43 \%$ & Ride \\
\hline Lampung Bank & $-0.21 \%$ & & Ride \\
\hline
\end{tabular}

Source : Processed by the Author

Based on the table above, it can be seen that the NPL ratio before the first quarter of 2020 ( before covid) increased in the second quarter of 2020 (after covid) such as for Bank Aceh, Bank Riau, Bank Nagari Sumatra, Bank 9 Jambi, Bank Bengkulu and Bank Lampung. On the other hand, there are 2 banks whose NPLs have decreased, namely Bank Sumut and Bank Sumsel. NPL reflects credit risk, the smaller the NPL, the smaller the credit risk borne by the bank, conversely, the higher this ratio, the lower the quality of bank credit, which causes the number of non- performing loans to increase. With this, the possibility of a bank in problematic conditions increasingly large, so it is possible the performance of the banks also experienced a decrease in the profit of the company will decrease. Bank Pembanggunan Regions (BPD) is a bank owned by the local government, such as provincial, district and municipalities that capital is comprised of shares shares which they invested in BPD them. The activity of this Regional Development Bank is to collect public funds such as in the form of savings and channel them back to the community in the form of credit and other forms. Besides that, BPD has a function and role as a partner of the government in the context of regional economic development, this is because BPD is able to open branches in serving the community to all corners of the region, BPD is referred to as a partner of the government in advancing regional development and regional economic development. In Indonesia, there are 26 BPDs in each province, and 8 BPDs are spread across Sumatra. From the background of this research, the author is interested in examining how the Covid 19 Pandemic Impact on Banking Financial Performance: A Study on Regional Development Banks in Sumatra.

\subsection{Problem}

From the background behind the research on the above can be formulated the problem as follows:

Is there a significant difference in the financial performance of Regional Development Banks across Sumatra as measured by ROA, ROE, NPL, LDR, and CAR between before the Covid-19 Pandemic and after the Covid-19 Pandemic?

\subsection{Research Objective}

Based on the formulation of the problem above, the research objectives can be obtained as follows: To analyze whether there are significant differences in the financial performance of Regional Development Banks throughout Sumatra between before the Covid-19 pandemic as measured by ROA, ROE, NPL, LDR, and CAR and after the Covid-19 pandemic . 19 ?

\section{THEORETICAL REVIEWS}

\subsection{Accounting}

The business world requires a tool that can be used as a tool in doing communication and interpretation to a system of information about the company's business activities, the tool is called Accounting. Accounting is referred to as an information system, where all business activities can be measured, the data is processed into information, namely in the form of reports and the output is communicated to decision makers or to stakeholders .

Reports Financial can be used as a tool to measure the performance of the company, by way of doing the analysis of the statements of financial the financial statements that either are reports that can provide benefits to the user, therefore, the financial statements must have a high quality as can be understood, consistency, helpless comparative, relevant, comparable and testable, therefore financial ratios can be obtained by making comparisons between existing items, both in the statement of financial position, income statement and statement of changes in equity.

\subsection{Financial Statement}

Financial statements are the final product of an accounting implementation process. The financial report has 5 (five) report components, each of which is an integral part of a complete financial report. The components of the 
financial statements are Balance Sheet, Profit and Loss Calculation, Cash Flow Statement, Statement of Changes in Financial Position or Statement of Changes in Retained Earnings, and Notes to Financial Statements . The balance sheet is a picture of the financial position . company at a specific time or date, usually December 31 . The calculation of the income provides information on income, middle-aged, and the financial performance of companies in a period of a certain, usually a period of one year commencing 1 January through to 31 December in the year the same. The cash flow statement describes all the sources of money coming in and what the money was spent on during a certain period. Changes in financial position describe changes in equity and changes in the company's profit and loss in a certain period. The notes to the financial statements are additional explanations so that the financial statements can be interpreted correctly.

According to the Indonesian Institute of Accountants (2017), the purpose of financial statements is to provide information regarding the financial position, performance and changes in financial position of an entity that is useful for a large number of users in making economic decisions . Report financial presented to stakeholder interests to assist them in making decisions the social, political, and economic so that decisions are taken can be more qualified (Mardiasmo 2018).

According to Supriyanto et al. (2010), Sabramayam and Wild (2009), and Ross et al . (2015), an analysis tool that is often used to measure the performance of finance in the field of finance are the ratios of finance. Ratio finance the use of data reports financial balance sheet and report profit and loss. Financial ratios can generally be divided into five groups (Horne \& Wachowicz, 2009).

Financial ratios can generally be divided into five groups (Horne \& Wachowicz, 2009).

1. Liquidity Ratio ( liquidity ratio )

a. Current ratio, with formulas assets smoothly divided by debt smoothly.

b. A cid-test ratio, with the formula for current assets minus inventories and the result is divided by current liabilities.

2. Debt Ratio ( leverage ratio)

a. Debt-to-equity ratio, with the formula debt divided by equity and can be measured by debt divided by equity .

b. Debt-to-total assets ratio. The formula is debt divided by total assets

3. Coverage Ratio ( coverage ratios)

The ratio is measured by intereset coverage ratio (ICR), with a formula of earnings before interest and taxes then divided denganbeban charge interest.

4. The ratio Activity ( Activity Ratios )

a. Recievable turnover, with the formula of net credit sales per year divided by receivables.

$b$. Inventory turnover, with the formula cost of goods sold divided by inventory.

c. Total assets turnover, with a formula of sales net divided by the number of aktivarata average.

5. Profitability Ratio

a. Gross profit margin, with the formula gross profit divided by net sales .

b. Net Profit Margin, with the formula net profit after tax divided by net sales.

c. Return on Assets ( $R O A$ ) with the profit after tax formula then divided by total assets

d. Ruturn on Equity ( $R O E$ ) with the formula profit after tax divided by own capital .

In past pandemics Covid-19 today, banks will face some possibility of risk, such as the risk of a credit standstill (NPL), the risk of the market and the risk of liquidity, as well as the risks Operational risks are at the end will have impact on the performance of financial banking

\subsection{Indicators of Financial Performance.}

Some indicators that become a measure of banking financial performance are usually : Return on Assets (ROA), Return on Equity (ROE), Non Performing Loans (NPL), Loan to Deposit Ratio (LDR), and Capital Adequacy Ratio (CAR).

2.3.1. Return on Assets (ROA)

Return on Assets (ROA) is an indicator of how profitable a company is relative to its total assets. ROA gives managers, investors, or analysts an idea of how efficiently a company's management uses its assets to generate revenue. "Return on assets is shown as a percentage. ROA is a ratio used to measure a bank's ability to earn a profit and a bank's level of business efficiency where the greater the ratio value indicates the bank's profitability is getting better or healthier" (Sahara \& Yanita, 2013).

According to the calculation of Return On Assets (ROA) Bank of Development of Regions in Indonesia that ROA Bank of Development of Regions experienced an increase, even though the condition of the economy globally in the years 2008-2011 in which many banks conventionally others experienced a decline, case is due to the Regional Development Bank lending most of the credit consumer to civil servants, so that his income is more secure than the credit more, and credit breakdown deemed not exist . 


\subsubsection{Return on Equity (ROE)}

Return on Equity (ROE) is an indicator of how profitable the company is relative to its total equity or equity . ROE shows to managers, investors, or analysts finance an idea about how well the company's management to use its equity to maximize revenue. "Return on equity is shown as a percentage ROE is the ratio used to measure the ability of banks to make profits and certain equity level where the greater value of the ratio indicates the level of profitability of capital own bank is getting better or getting healthier.

2.3.3. Non- Performing Loans (NPL)

Risk Profile is a component of bank soundness assessment which can be measured by credit risk by using the Non Performing Loan (NPL) ratio which is calculated based on the comparison between the number of non- performing loans and total loans. NPL ratio to measure a bank's ability to keep the risk of failure of repayment of credit by the debtor. Credit problems are defined as the risk that is associated with the possibility of failure of the client to pay its obligations or the risk that the debtor can not repay their debts. NPL reflects the credit risk, the smaller the NPL, the less the credit risk that is borne by the bank. So that the value of the bank against the ratio is good, the FSA set criteria for the ratio of NPLs net at under 5\%. The higher this ratio , the lower the quality of bank credit, which causes the number of non-performing loans to increase. With this, the possibility of a bank on condition bermasalah.semakin large, so it is possible the performance of the banks also decreased the profit of the company will decrease.

2.3.4. Loan to Deposit Ratio (LDR)

Liquidity risk is measured using LDR, which is a ratio to assess a bank's liquidity by dividing the amount of credit extended by the bank to third party funds. LDR has a positive influence on profit changes, meaning that if this ratio shows a high number, then the profit change is also high and vice versa, it can be interpreted that if this ratio shows a low number, the bank is in idle money or excess liquidity which will cause the bank to lose opportunity to earn more profit .

The amount of the LDR is considered to meet the requirements if the amount of the LDR is between $78 \%$ to $92 \%$. LDR was below the target can be said that the bank maintains the tool liquid that excessive and this will cause pressure on bank earnings in the form of high maintenance costs are idle cash. The higher the LDR, the profit earned by the bank will increase with the assumption that the bank is able to channel its credit effectively so that the number of bad loans is expected to be low.

2.3.5. Capital Adequacy Ratio (CAR).

CAR is often used as a benchmark by the OJK to see the soundness of a bank, the higher the CAR the bank is considered the healthier the bank, and the lower the CAR of a bank is considered the more unhealthy the bank is.

\subsection{Hypothesis}

Based on the foundation of theory and research earlier in the above, can the authors formulate the research hypothesis as follows : There is a difference of Financial Performance for the indicator ratios ROA, ROE, NPL, LDR and CAR on Province Development Bank in Sumatra before and after the Pandemic covid-19.

\section{RESEARCH METHOD}

\subsection{Research Objectives}

The object of this research is the Regional Development Bank in Sumatra at the end of 2019-2021. The number of Regional Development Banks registered with OJK is 8 banks and the names can be seen in the Appendix.

\subsection{Methods}

The research method used in this study is a survey method, which collects data (information) from regional development banks included in the research object. While the data used is secondary data, both directly taken from the research object company and data from the OJK.

\subsection{Population and Sample}

Total population of the company that became the object of research is 8 Bank Development Regions are active in Sumatra until year 2021.Penelitian using the Sampling saturated, because the determination of the sample by using all the population that all Regional Development Banks se Sumatra.

\subsection{Operalization of Variables}

Variables that are used in research this is as follows:

(1) Return On Assets (ROA)

This ratio is used to measure the ability of bank management in obtaining overall profits. The greater the ROA of a bank, the greater the level of bank profits and the better the bank's position in terms of asset use

(2) Return On Equity (ROE)

This ratio is used to measure the ability of bank management to gain profit from the amount of equity investment 
invested. Increasingly large ROE of a bank, the greater the level of bank profits and the better also the position of the bank on the terms of the use of capital.

(3) Net Performance Loan (NPL). To measure credit risk, the researcher uses NPL. This ratio shows that the ability of bank management in managing non-performing loans provided by banks. The higher this ratio, the worse the quality of bank credit which causes the number of non-performing loans to increase (Almilia and Herdiningtyas, 2005).

(3) Loan to Deposit Ratio (LDR)

The liquidity ratio that is often used in assessing the performance of a bank is the LDR (Loan to Deposit Ratio), which is the ability of the bank to fulfill its obligations. This ratio for assessing the liquidity of a bank by way of dividing the amount of credit that is granted by the bank to fund the third.

The higher this ratio, the lower the liquidity capacity of the bank concerned, so the possibility of a bank in troubled conditions will be even greater.

(4) Capital Adequacy Ratio (CAR)

The capital ratio used in this study is the Capital Adequacy Ratio. CAR is the minimum capital requirement ratio that must be owned by a bank. The higher the CAR ratio, themore capable the bank is in managing assets that contain risk.

\subsection{Collecting Data Techniques}

Mechanical collection of data is done by using Data Secondary Data Secondary taken from the website of each Bank Development Regions se Sumatra . Reports are taken is a report publication quarterly data before covid 19 which quarter II, III , IV in 2019 and the first quarter of 2020, the data after covid 19, namely Quarter II, III and IV of 2020 and the first quarter of 2021 this data is processed by using the help SPSS software.

\subsection{Data Analysis Method}

In this study using quantitative analysis methods . Both are descriptive and inferentially. Descriptive analysis is done by making a direct tabulation of the data to be analyzed, then comparing the percentage and average values . Furthermore, the inferential analysis to see the impact of covid-19 on the financial performance of regional development banks is used the $t$ test difference test. This research hypothesis testing utilizes the analysis technique of the independent sample test ( Independent sample t-test) (Santoso, 2000). Although the descriptive analysis obtained by differences in financial performance, not necessarily with the test analysis of the difference of two samples independently demonstrate the difference of performance between before and after covid 19. The study is put on test different two samples indepeneden because the data of the company before and after covid 19, the same type and amount. The two independent sample test requires the processed data to be normally distributed.

\section{RESULTS AND DISCUSSION}

\subsection{Descriptive Analysis}

A nalisis Descriptive statistics illustrate how the circumstances of each financial ratio of the mean, the number of samples, standard deviation and standard error of mean, descriptive analysis is done by classifying each of data financial ratios into two groups: the ratio before covid and after covid, the picture can be seen from table 4.1 below:

\section{Table 4.1}

Descriptive statistics

\begin{tabular}{|ll|r|r|r|r|}
\hline & & mean & N & Std. Deviation & Std. Error Mean \\
\hline Pairs 1 & NPL Before Covid & 2.6438 & 32 & 1.68025 &, 29703 \\
& NPL After Covid & 2.3994 & 32 & 1.32943 &, 23501 \\
Pair 2 & ROA Before Covid & 2.2113 & 32 &, 58595 &, 10358 \\
& ROA After Covid & 3,2350 & 32 & 5,10324 &, 90213 \\
Pair 3 & ROE Before Covid & 16.6569 & 32 & 6.12768 & 1.08323 \\
& ROE After Covid & 16.7044 & 32 & 4.33758 &, 76678 \\
Pairs 4 & LDR Before Covid & 82.7294 & 32 & 11.02643 & 1.94922 \\
& LDR After Covid & 81.5384 & 32 & 8.88384 & 1.57046 \\
Pair 5 & CAR Before Covid & 132.1550 & 32 & 443,60087 & 78,41830 \\
& CAR After Covid & 121.1956 & 32 & 2.30708 &, 40784 \\
\hline
\end{tabular}

Source: SPSS data processing results, 2021

From the processed data above, it can be explained the mean, amount of data, standard deviation, and standard error of the mean for each ratio as below:

1. NPL ratio before and after covid.

There were 32 samples used in the study (N-32), both for the ratio before and after covid. The mean before and after covid is 2.6438 and 2.3994, respectively, meaning that there is a difference in NPL before covid and after 
covid, where there is a decrease in the average NPL, which is 0.2444 from before the onset of covid. The lower the NPL indicates the lower the credit risk, thus providing a good signal for the bank. This condition is still within the limit set by BI, namely 5\%. The standard deviation is 1.68025 and 1.32943 , this value is slightly away from 0 which indicates the distribution of the data is too diverse so that the mean cannot be used as a parameter to represent the data in the study. The standard error of mean of 0.29703 and 0.23501 indicates that the mean deviation is not that large .

2. ROA ratio before and after covid.

There were 32 samples used in the study (N-32), both for the ratio before and after covid, the mean before and after covid was 2.2113 and 3.2350, respectively, meaning that there was a difference in ROA before and after covid, where there was a the average increase in ROA is $1.0237(102.37 \%)$ from before the onset of covid. The higher the ROA indicates the higher the return that will be received so that it brings profits to the bank. ROA data in the sample period is still within the BI rules, namely $>1.5 \%$. Standard deviation of 0.58595 and 5.10324, this value is slightly away from 0 which indicates the distribution of the data is too diverse so that the mean cannot be used as a parameter to represent the data in the study. The standard error of mean of 0.10358 and 0.90213 indicates that the deviation of the mean is not that big .

3. ROE ratio before and after covid.

There were 32 samples used in the study (N-32), both for the ratio before and after covid. The mean before and after covid was 16.6569 and 16.7044, respectively, meaning that there was a difference in ROE before and after covid, where there was an increase in the average ROE of 0.0475 from before the onset of covid. The higher the ROE indicates the higher the return that will be received by the Bank, thus bringing profits to the bank. The standard deviation of 6.12768 and 4.33758 this value is slightly away from 0 which indicates the distribution of the data is too diverse so that the mean cannot be used as a parameter to represent the data in the study. The standard error of mean is 1.08323 and 0.76678 , indicating that the mean deviation is not that big.

4. LDR ratio before and after covid.

There were 32 samples used in the study (N-32), both for the ratio before and after covid. The mean before and after covid was 82.7294 and 81.5384, meaning that there was a difference in LDR before and after covid, where there was a decrease in the average LDR, which was 1.191 (119\%) from before the onset of covid. The lower the LDR, the better for the Bank, which indicates the lower liquidity risk will bring good for the bank. The LDR data in the sample for this period is still within BI regulations, which is still between $78-92 \%$. Data Standard deviation is 11.02643 and 8.88384 , this value is slightly away from 0 which indicates the distribution of the data is too diverse so that the mean cannot be used as a parameter to represent the data in the study. The standard error of mean of 1.94922 and 1.57046 shows that the mean deviation is not that big .

5. CAR ratio before and after covid.

There were 32 samples used in the study (N-32), both for the ratio before and after covid. The mean before and after covid is 132.1550 and 121.1956 , respectively, meaning that there is a difference in CAR before covid and after covid, where there is a decrease in the average CAR of 10.9594 from before the onset of covid, but it is still at the minimum standard required. determined by BI is $8 \%$. Standard deviation of 443.6008 and 102.3070 , this value is slightly away from 0 which indicates the distribution of the data is too diverse so that the mean cannot be used as a parameter to represent the data in the study. The standard error of mean is 78.4183 and 10.23501 , indicating that the mean deviation is not that big.

Before conducting the test to analyze the differences in the financial performance of Bank BPD throughout Sumatra before and after the announcement of Covid 19, it was first determined whether the collected financial data had a normal distribution, namely by conducting the Normality test, after being tested, the Paired sample ttest analysis was carried out. for data with normal distribution and Wilcoxon test for data with abnormal distribution processed using SPSS.

4.2. Normality test.

The following is a descriptive statistical description for the Normality Test can be seen from table 4.2 below. 
Table 4.2

Descriptive Statistics Test for Normality. Tests of Normality

\begin{tabular}{|l|r|r|r|r|r|r|}
\hline & \multicolumn{3}{|c|}{ Kolmogorov-Smirnov a } & \multicolumn{3}{c|}{ Shapiro-Wilk } \\
\cline { 2 - 7 } & Statistics & df & \multicolumn{1}{c|}{ Sig. } & Statistics & df & \multicolumn{1}{c|}{ Sig. } \\
\hline NPL Before Covid &, 196 & 32 &, 003 &, 882 & 32 &, 002 \\
NPL After Covid &, 201 & 32 &, 002 &, 894 & 32 &, 004 \\
ROA Before Covid &, 212 & 32 & .001 &, 917 & 32 & 0.018 \\
ROA After Covid &, 441 & 32 &, 000 &, 266 & 32 &, 000 \\
ROE Before Covid &, 104 & 32 &, $200 *$ &, 976 & 32 &, 678 \\
ROE After Covid &, 121 & 32 &, $200 *$ &, 970 & 32 &, 500 \\
LDR Before Covid &, 087 & 32 &, $200 *$ &, 970 & 32 &, 496 \\
LDR After Covid &, 139 & 32 &, 123 &, 948 & 32 &, 122 \\
CAR Before Covid &, 535 & 32 &, 000 &, 268 & 32 &, 000 \\
CAR After Covid &, 167 & 32 &, 024 &, 907 & 32 &, 009 \\
\hline
\end{tabular}

*. This is a lower bound of the true significance.

a. Lilliefors Significance Correction

Source: SPSS data processing results, 2021

For normality testing, Kolmogorov-Smirnov is used because $\mathrm{N}>30$ is 32 samples with the condition that the data must be normally distributed with a Sig level $>0.05$. From the table above, it can be seen that the ROE and LDR data have a significance of $2.00>0.05$ and 2.00 and $0.123>0.05$ respectively, so that the data is normally distributed both for data before and after the covid announcement so that it meets the requirements for data processing using Paired Samples t-test. . While the NPL, ROA and CAR data have a significance of $<0.05$ so that the data is not normally distributed both for data before and after the covid announcement and will be processed using the Wilcoxon test .

\subsection{Hypothesis testing}

Hypothesis testing can be done using 2 types of tests, namely:

a. Paired Samples test for normally distributed data, namely the ratio of ROE and LDR can be seen below: From the Paired Sample Test table above, it contains the mean paired differences which show the difference between the average results before and after the decision criteria as follows:

- $\quad$ If the value of $\mathrm{Sig}<0.05$ then $\mathrm{H} 0$ is rejected and Ha is accepted (there is a difference)

- If the value of Sig $>0.05$ then $\mathrm{HO}$ is accepted and $\mathrm{Ha}$ is rejected (there is no difference)

By using a $95 \%$ confidence interval, it can be explained as follows:

1. The result for ROE shows that there is a difference in the average ROE of 0.4750 between before Covid and after Covid, where the ROE after Covid is higher than before Covid. For the ROE ratio, the significant level ( 2 tailed) is 0.968 meaning $>0.05$ so $\mathrm{H} 03$ is accepted and Ha3 is rejected. This means that there is no difference between ROE before covid and after covid, so it can be concluded that the ROA variable data has no difference in financial performance or there is no impact on performance before Covid and after Covid.

2. The result for the LDR shows that there is a difference in LDR of 1.1904 between before Covid and after Covid, where the LDR after Covid is lower than before Covid. For the LDR ratio, the significant level ( 2 tailed) is 0.378 , meaning $>$ from 0.05 so H04 is accepted and Ha4 is rejected. This means that there is no difference between LDR before covid and after covid, thus it can be concluded that there is no difference in financial performance or there is no impact on financial performance (LDR) before Covid and after Covid.

b. Wilcoxon test for data that is not normally distributed, namely the ratio of NPL, ROA and CAR can be seen in the following table:

Table 4.3

DIFFERENT TEST WITH WILCOXON TEST FOR NPL, ROA \& CAR Test Statistics a

\begin{tabular}{|l|r|r|r|}
\hline & $\begin{array}{l}\text { NPL After Covid - } \\
\text { NPL Before Covid }\end{array}$ & $\begin{array}{r}\text { ROA After Covid - ROA } \\
\text { Before Covid }\end{array}$ & $\begin{array}{c}\text { CAR After Covid - CAR } \\
\text { Before Covid }\end{array}$ \\
\hline Z & $-2,263 \mathrm{~b}$ & $-1,333 \mathrm{c}$ & $-2.851 \mathrm{c}$ \\
asymp. Sig. (2-tailed) &, 024 &, 183 &, 004 \\
\hline
\end{tabular}

a. Wilcoxon Signed Ranks Test

b. Based on positive ranks. 
The Wilcoxon Test table above contains the value of Z Value, Asymp.sig (2 tailed) for each NPL, ROA and CAR ratio both before Covid and after Covid which shows the difference between the average results before and after the decision criteria as follows:

- If the value of Asymp.Sig. (2-tailed) $<0.05$ then there is a significant difference between the values before and after (Hypothesis Accepted)

- If Asymp Value .Sig. (2-tailed) $>0.05$ then there is no significant difference between the values before and after (Hypothesis Rejected).

Based on the test in table 5.4 above using a $95 \%$ confidence interval, it can be explained as follows:

1. Table 4.3 shows that there is a $-2,263$ difference in NPL between after Covid and before Covid, where NPL after covid is lower than before Covid. For the NPL ratio, the Asymp.sig (2 tailed) level is 0.024 meaning $<0.05$ so H0 1 is rejected and Hal is accepted This means that there is a difference between NPL before covid and after covid, thus it can be concluded that there is a difference in financial performance or there is an impact on financial performance (NPL) before Covid and after Covid

2. Table 3.3 shows that there is a difference in ROA of -1.133 between after Covid and before Covid, where the ROA after Covid is higher than before Covid. To Ratios ROA Asymp.Sig level (2-tailed) was .183 meaning $>$ 0:05 so that H02 is accepted and Ha2ditolak, This means there is no difference between the ROA before covid with after covid, thus we can conclude that there are differences in financial performance or no performance impact finance (NPL) before covid and after covid.

3. Table 434 shows that there is a CAR difference of -2.851 between after Covid and before Covid, where the CAR after Covid is lower than before Covid. For Asymp.sig ( 2 tailed) CAR ratio is 0.004 meaning < from 0.05 so $\mathrm{H} 05$ is rejected and Ha5 is accepted, This means that there is a difference between CAR before covid and after covid, thus it can be concluded that there are differences in financial performance or there is a performance impact finance (NPL) before covid and after covid.

\subsection{Recapitulation of Hypothesis Testing Results can be seen in table 4.4 below:}

Table 4.4

Recapitulation of Hypothesis Test Results

\begin{tabular}{|c|c|c|c|c|}
\hline Hypothesis & description & Asim sig & Sig. & Information. \\
\hline 1 & $\begin{array}{l}\text { there is a difference in financial performance } \\
\text { using NPL between before covid and after } \\
\text { covid. }\end{array}$ & 0.024 & 0.05 & $\begin{array}{c}\text { Accepted } \\
\text { Covid impacts financial } \\
\text { performance (NPL) }\end{array}$ \\
\hline 2 & $\begin{array}{l}\text { There is no difference in financial } \\
\text { performance using ROA between before } \\
\text { covid and after covid (no impact by Covid) }\end{array}$ & 0.183 & 0.05 & $\begin{array}{c}\text { Rejected } \\
\text { Covid has no impact on financial } \\
\text { performance } \\
\text { (ROA) }\end{array}$ \\
\hline 3 & $\begin{array}{l}\text { There is no difference in financial } \\
\text { performance using ROE between before } \\
\text { covid and after covid. }\end{array}$ & 0.968 & 0.05 & $\begin{array}{c}\text { Rejected } \\
\text { Covid has no impact on financial } \\
\text { performance } \\
\text { (ROE) }\end{array}$ \\
\hline 4 & $\begin{array}{l}\text { There is no difference in financial } \\
\text { performance using LDR between before } \\
\text { covid and after covid. }\end{array}$ & 0.378 & 0.05 & $\begin{array}{c}\text { Rejected } \\
\text { Covid has no impact on financial } \\
\text { performance } \\
\text { (LDR) }\end{array}$ \\
\hline 5 & $\begin{array}{l}\text { There is a difference in financial performance } \\
\text { using CAR between before covid and after } \\
\text { covid. }\end{array}$ & 0.004 & 0.05 & $\begin{array}{l}\text { Accepted. } \\
\text { Covid has an impact on financial } \\
\text { performance } \\
\text { (CAR) }\end{array}$ \\
\hline
\end{tabular}

\section{CONCLUSION AND SUGGESTION}

\subsection{Conclusion.}

Based on the results of the analysis and testing carried out, it can be concluded that the occurrence of Covid 19 impacted the financial performance of Province Development Banks throughout Sumatra as follows:

1. The financial performance criteria affected by Covid 19 were the NPL ratio and the CAR ratio. 
2. Financial performance criteria that were not affected by Covid 19 is the ROA ratio, ROE Ratio and LDR Ratio

\subsection{Suggestion}

To anticipate a bigger impact with the Covid 19 , it is recommended that the Bank's management continue to apply the precautionary principle and mitigate banking risks that arise due to this Covid Pandemic-19.

\section{References}

Akins (2017) "Financial Reporting Quality and Uncertainty about Credit Risk among Rating Agencies" The Accounting Review, Volume 93, Page 1 . October 2017.

Alim, S. (2014). Analysis of the Effect of Inflation and BI Rate on Return on Assets (ROA) of Regional Development Banks in Indonesia. Journal of Modernization Economics , 10

Barth (2014) "Measurement in Financial reporting: The Need for Concepts." Accounting Horizons, Volume 28, Page 331 . December 2013

Blondi, Glover, Jamal, Ohlson, Penman, Sunder, and Tsujiyama (2012) "Some of conceptual tension in Financial reporting.” Accounting Horizons, Volume 26, Page 125 . March 2012.

Capps, Koonce, and Petroni (2016) "Natural Optimism in Financial Reporting: A State of Mind." Accounting Horizons, Volume 30, Page 79 . September 2015.

Disemadi, HS, \& Salih, AI (2020). Banking credit restructuring policy amid COVID- 19 pandemic in Indonesia. Journal of Economic Innovation , 5 (2).

Easton (2016) “Financial Reporting: An Enterprise Operation Perspective.” Journal of Financial Reporting , Volume 1, Page 143 . September 2015.

Fauziah, H. N., Fakhriyah, A. N., \& Rohman, A. (2020). Operational Risk Analysis of Regional Development Banks During the Covid-19 Pandemic. Al-Intaj: Journal of Regional Development Economics and Banking , $6(2)$,

Hadiwardoyo, W. (2020). National Economic Losses Due to the Covid-19 Pandemic .

Harry. (2015). Financial Statement Analysis . Yogyakarta: CAPS.cashmere. (2017). Financial Statement Analysis . Jakarta: PT Rajagrafindo Persada. Landsman and Peasnell (2013) " the Changing Landscape of banking and the Challenges it Poses for Accounting Financial Reporting” Accounting Horizons, Volume 27, Page 757. December 2013.

Liang, Marinovic and Varas , (2018)., The Credibility of Financial Reporting : A Reputation Based Approuch. The Accounting review, Volume 93 , Page 317, Issue 1. 2017.

Miswanto. Vajrin, SA (2019). Analysis of financial performance after the pre- 2008 global economic crisis in manufacturing companies in Indonesia. Journal of accounting, auditing and finance, vol 16.

Naryono, E. (2020). Impact of National Disaster COVID-19, Indonesia Towards EconomicRecesion .

Nuzul Ikhwal. "Analysis of ROA and ROE on Bank Profitability on the Indonesia Stock Exchange ". Journal of Financial Institutions and Banking , Vol.1, No.2, (July- December 2016), 212-227.

Popita, M. S. A. (2013). Analysis of the causes of non- performing financing in regional development commercial banks in Indonesia. Accounting Analysis Journal , 2 (4).

Purbaningsih, RYP, \& Fatimah, N. (2014). The effect of liquidity risk and non- performing financing (NPF) ratio to commercial Sharia bank profitability in Indonesia. LTA, $60(80), 100$.

Putri, Y. F., Fadah, I., \& Endhiarto, T. (2010). Analysis comparison of the performance of financial bank of conventional and bank development area. Journal of Economics, Accounting and Management, 14 (1).

Sabramayam, K., \& Wild, J. (2009). Financial statement analysis. New York:McGraw Hill Companies Inc.

Sari, TM; Sham, D.; \& Ulum, I. 2012. The effect of non-performance loans as a result of the global financial crisis on the profitability of banking companies . Journal of Accounting \& Investment, 13 (2).

Ningsih,M. R., \& Mahfudz, M. S. (2020). Impactof the Covid-19 Pandemic Management of the Islamic Banking Industry : Comparative Analysis . POINTS , 2 (1).

Ruslim. 2012. Analysis of the Effect of Capital Adequacy Ratio (CAR), Non Performing Loan (NPL), and Loan to Deposit Ratio (LDR) on Return On Assets (ROA) at Islamic Commercial Banks Registered at Bank Indonesia. Islamic Banking Journal , 1 (1).

Sabramayam, K., \& Wild, J. (2009). Financial statement analysis. New York:McGraw Hill Companies Inc.

Author: Afrizal (D'04-D'08--CH '15--'19). Dean of Economics Faculty of Jambi University (2004-2008), Dean of Economics Faculty of Jambi University (2008-2012), Chairman of Indonesia Accountants Institute for Jambi Province (2015-2019). Birth: 27 July 1969 Bukittinggi, Indonesia. Education: Bachelor in Accounting at Andalas University, Padang, Indonesia. Master in Accounting 1996 at Padjadjaran University, Bandung, Indonesia. Doctor in Accounting 1999 at Padjadjaran University, Bandung, Indonesia. 